\title{
The Pleistocene contribution to the net erosion and sedimentary conditions in the outer Bear Island Trough, western Barents Sea
}

\author{
Krzysztof Jan Zieba $^{1} \cdot$ Maarten Felix $^{1} \cdot$ Jochen Knies $^{2,3}$
}

Received: 7 January 2016/Accepted: 3 June 2016/Published online: 22 July 2016

(C) Springer-Verlag Berlin Heidelberg 2016

\begin{abstract}
The Pleistocene sedimentary conditions and the glacial contribution to net erosion were determined for the outer Bear Island Trough by using a Monte Carlo-type method. The approach uses ages for glacial/interglacial periods that were based on the regional ice-sheet volume curve. The results indicate that the western Barents Sea was glaciated during four marine isotope stages: MIS 16 (635.6-624.7 ka), MIS 12 (438.7-428.0 ka), MIS 6 (138.6-134.6 ka) and MIS $2(19.3-16.0 \mathrm{ka})$ for a total duration of $29 \mathrm{ka}$. The first glacial event (before $440 \mathrm{ka}$, MIS 16) resulted in homogeneous erosion over the study area (with an erosion rate of $24.2 \pm 8.5 \mathrm{~mm} / \mathrm{a}$ ). After $440 \mathrm{ka}$, a change in sedimentary conditions resulted in inhomogeneous erosion rates over the study area from $-12.6 \pm 1.6$ (i.e. net deposition) to $1.6 \pm 1.8 \mathrm{~mm} / \mathrm{a}$ (i.e. net erosion). The most likely values of average deposition rates during interglacial periods were modelled as $0.12 \pm 0.1 \mathrm{~mm} / \mathrm{a}$. In the outer Bear Island Trough the net erosion was found to be mainly the effect of tectonic uplift and subsequent erosion prior to the glacial ages. The results show that in most parts of the study area the Pleistocene glacial contribution to the total net erosion was small: the most likely glacial contribution in the eastern part of the
\end{abstract}

Krzysztof Jan Zieba

krzysztof.j.zieba@ntnu.no

1 Department of Geology and Mineral Resources Engineering, NTNU-Norwegian University of Science and Technology, Sem Sælands veg 1, 7491 Trondheim, Norway

2 Geological Survey of Norway, Leiv Eirikssons vei 39, 7040 Trondheim, Norway

3 Department of Geology, CAGE-Centre for Arctic Gas Hydrate, Environment and Climate, University of Troms $\varnothing$, 9037 Troms $\varnothing$, Norway area reaches $100 \mathrm{~m}$, which is about $9 \%$ of the total net erosion, while in the westernmost part the glaciations did not contribute to the net erosion.

Keywords Barents Sea $\cdot$ Net erosion · Glaciations · Uplift

\section{Introduction}

The history of erosion in the Barents Sea during the Cenozoic is complex, as it was caused by both tectonics and glacial processes [9, 12-14, 24, 54]. Tectonic uplift is normally attributed to plate reorganization in the Norwegian-Greenland Sea during the Cenozoic [12, 53]. Different ages and magnitudes of net erosion, defined as total erosion minus total deposition thickness, have been suggested for the Cenozoic [9]. The differences in these ranges are attributed to the indirect nature of the methods used for determination of the erosion timing as well as the complex and inhomogeneous uplift history in the western Barents Sea [12, 21]. In contrast, glacial erosion thickness estimates $[16,20,34]$ are well constrained and show lower discrepancy. The glacial erosion thickness values were estimated based on measured volumes of glacial erosion products that were deposited on the outer shelf and continental slope areas. The glacial contribution to the net erosion can, however, also be controlled by on-shelf deposition that counteracts the process of glacial erosion. The amino acid dating of Sættem et al. [62] demonstrated that the outer shelf's Pleistocene sediments were deposited not only during the Last Glacial Maximum (LGM), but also during several cold and warm periods. Glacial and interglacial depositions are especially important in the outer shelf areas of the western Barents Sea, which experienced both extensive erosion and deposition during the Pleistocene 
[20, 34]. However, the on-shelf deposition rates have never been calculated, so the net erosion effect of glacial processes is not known.

In addition, definite ages of glacial and interglacial periods during the Pleistocene, and especially prior to the Saalian ( $>0.14 \mathrm{Ma})$ are uncertain $[30,40,61]$. The chronology based on ice-rafted debris (IRD) analysis lacks well-defined ages of the glacial periods and precise ice sheet limits. The presence of the ice sheet cannot be based on the 41 and $100 \mathrm{ka}$-long glacial-interglacial cycles either, because ice sheets were probably only present on the Barents Sea shelf for relatively short intervals [17, 61]. In addition, the approximations of the glacial ages may not be valid everywhere, such as in the deep areas close to the western shelf margin [36], so that estimates can only be used locally.

The net Cenozoic erosion thickness in the western Barents Sea varies considerably depending on location; estimates range from 0 to more than $3 \mathrm{~km}$, with a general increase towards the east and north [24]. It is, however, unclear which of the erosion mechanisms (tectonic or glacial) had the most important role in generating net erosion. The literature estimates of the ratio of glacial-totectonic erosion have been determined using different methods such as apatite fission-track modelling [48], vitrinite reflectance [48, 49], temperature data modelling [9, 14] and sediment volume calculations [12]. The estimates vary significantly and range from $2: 1$ to $1: 2$ $[9,12,14,48,49]$. The estimates do not normally account for regional variations. The lack of differentiation between tectonic and glacial erosion thus means it has not been possible to obtain a full understanding of it either.

This issue is addressed here in the outer Bear Island Trough (Bjørnøyrenna), western Barents Sea, which represents a transition area from dominantly erosive Barents Sea shelf to mostly depositional outer shelf and continental slope [18]. This paper evaluates the Pleistocene contribution to the net erosion [24] by calculating glacial erosion and deposition rates and thereby the sediment balance of the study area during the Pleistocene. The sediment budget calculations are performed by using a Monte Carlo-type simulation. The simulation input consists of Holocene interglacial deposition rates [27, 55], average on-shelf erosion values [34] and glacigenic cover thickness obtained from wells (as reported by the Norwegian Petroleum Directorate, http://factpages.npd.no/). The advantage of the method is that it assesses local glacial sedimentary conditions which can be inhomogeneous over glaciated catchment areas [22]. The calculations use glacial/interglacial ages based on regional ice volume estimates of de Boer et al. [11]. These ages provide new estimates of erosion/deposition rates for much shorter timescales than was possible before, being based on the time periods when the ice sheet was actually present in the study area. The resulting values of glacial erosion can then be compared to the total net erosion estimates to understand the relative importance of glacial vs. tectonic processes in this area.

\section{Study area and geological setting}

The Barents Sea is a large epicontinental sea bounded to the north and west by passive continental margins developed during the Cenozoic opening of the NorwegianGreenland Sea and the Eurasia basin [19]. The Cenozoic rifting and related plate reorganization in the NorwegianGreenland Sea is often thought to have been the main mechanism causing uplift and erosion in the western Barents Sea [26]. The tectonic uplift and erosion occurred during the Eocene-Oligocene transition and during the Miocene-Pliocene [3, 21, 26]. The latter phase resulted in subaerial exposure of the Barents Sea until the Early Pleistocene (until $\sim 1.6 \mathrm{Ma}$ in the Bear Island Trough, $[7,12,31])$.

The southern Barents Sea is thought to have been repeatedly glaciated by the Eurasian ice sheet since about 1.0 Ma [30, 33]. Thanks to extensive research since the 1990s (described in detail by Ingólfsson and Landvik [25]), the youngest glacial history has been reconstructed. Little is known about the glaciations prior to the Saalian. The Saalian glaciation (>140 ka) which occurred during Marine Isotope Stage 6 (MIS 6), covered the entire Barents Sea, reaching the edge of the western and northern Barents Sea shelf and depositing a regional till unit [61, 62]. During the Lower Weichselian (100-90 ka, MIS 5d) the northern and eastern parts of the Barents Sea were glaciated, leaving the south-southwestern part ice-free [61]. The Barents Sea ice sheet also reached the western and northern shelf breaks during the Middle Weichselian (70-65 ka, MIS 4). During the Late Weichselian (25-15 ka, MIS 2) the entire Barents Sea was covered by the ice sheet leaving a till unit over large shelf areas [39, 51].

The Pleistocene glaciations lead to sediment redistribution and left a significant imprint on the Barents Sea geomorphology [1, 2, 5, 67]. At present, the seabed consists of shallow banks (100-200 m below sea level) and troughs down to $500 \mathrm{~m}$ below sea level, one of which is the Bear Island Trough. The sediments eroded from the Barents Sea shelf by glacial and earlier pro-glacial processes were deposited on the outer shelf and in the largest mouth fan in the Arctic-the Bear Island Trough Mouth Fan, which was developed at the mouth of the Bear Island Trough on the continental slope [34, 63]. The study area contains wells that are located at the proximal end of the fan (Fig. 1). 


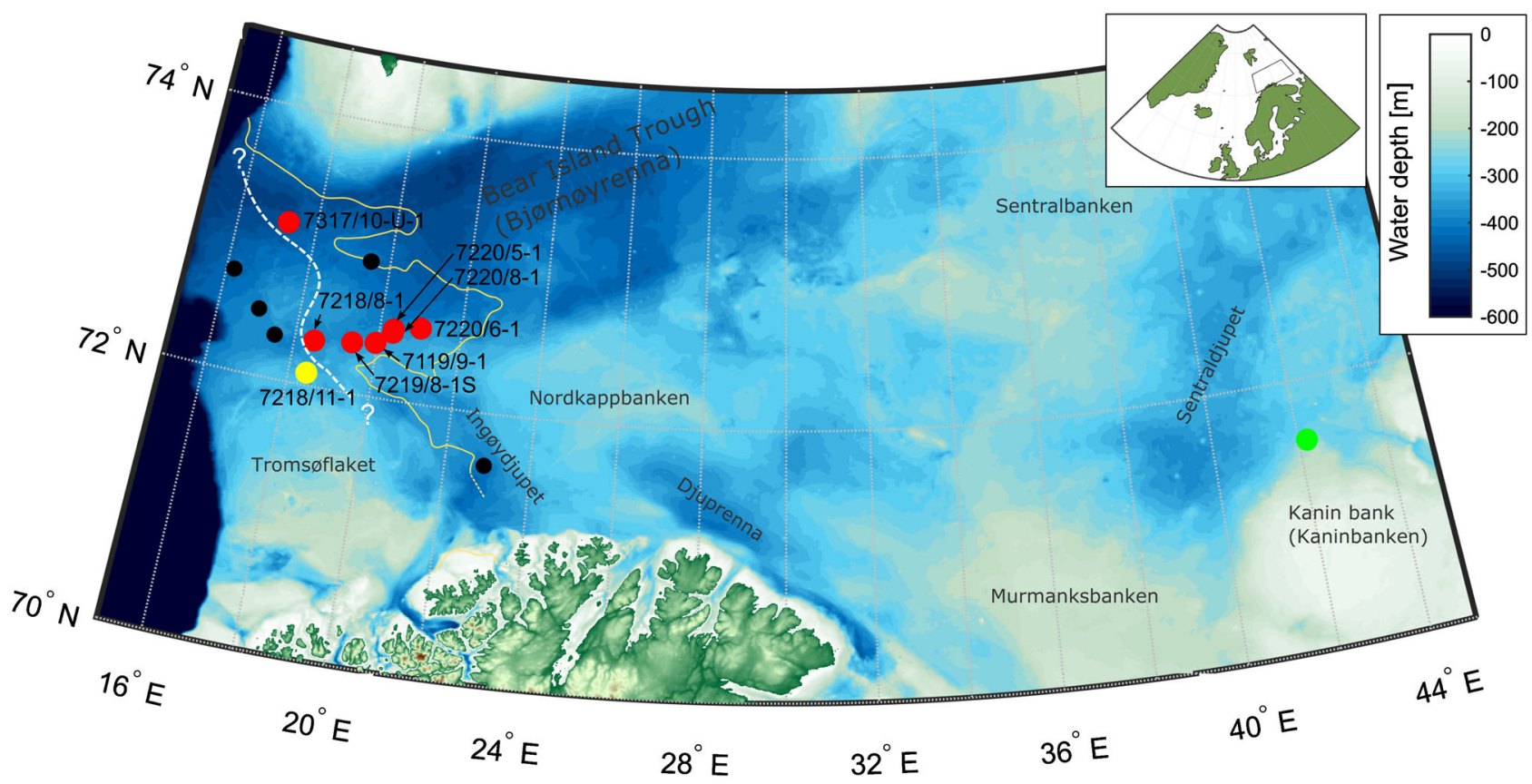

Fig. 1 Bathymetry of the western-central Barents Sea. The solid orange line separates areas where glacial deposits from different ages were preserved and where only the youngest deposits are present (see main text for explanation). The core location where glacial ages were determined for the eastern Barents Sea [52] is shown as a green dot. The locations of the cores used to determine Holocene sedimentation rates are shown as small black dots. The locations of the wells used

On seismic profiles, the glacial deposits are separated from the underlying pre-glacial rocks by a prominent reflector-the upper regional unconformity (URU) [59]. Internally, deposits above the URU are bounded by several unconformities that act as seismic reflectors. The most prominent are reflectors $\mathrm{R} 7, \mathrm{R} 5$, and $\mathrm{R} 1$, which, together with the seafloor, separate sediment packages GI, GII and GIII [18]. The age of reflector R7 is dated at $\sim 2.7-2.3 \mathrm{Ma}$, $\mathrm{R} 5$ at $\sim 1.5 \mathrm{Ma}[30,45]$ and $\mathrm{R} 1$ at $\sim 700-440 \mathrm{ka}$ $[16,33,62]$. Package GI is formed by sediments eroded from the Barents Sea region by fluvial and glaciofluvial processes [34] when the Barents Sea region was an unglaciated subaerial corridor between glaciated Svalbard and northern Scandinavia [7, 30]. The overlying sediment packages GII and GIII consist of sediments eroded from the Barents Sea shelf by glacial advances reaching the shelf break and deposited in the glaciomarine environments on the outer shelf and on the continental slope [7, 34, 36]. The identified packages were correlated with well data from well 7216/11-1S located in the outer shelf area providing a critical framework for the upper Cenozoic stratigraphy [30].

Except for the outermost parts, only package GIII is present on the Barents Sea shelf. In the inner parts of the shelf sequence GIII consists of a thin veneer of the glacial deposits younger than $30 \mathrm{ka}$ (see Fig. 1, [62, 64]). Further

here are shown as red and yellow dots with well names. The yellow dot represents the well that shows no glacial contribution to the net erosion within its uncertainty range; the rest of the wells (red dots) show some contribution to the net erosion. The dashed white line represents a conceptual boundary between these areas (see main text for discussion)

west, including in the study area, the sequence consists of a glacigenic succession deposited during several glacial and interglacial events [62].

Despite the major uncertainty in pre-Saalian glacial extent, Faleide et al. [18] and Laberg et al. [34] pointed out some similarities in glaciation patterns during the deposition of packages GII and GIII (in this study these are taken to be from 1.5 to $0.44 \mathrm{Ma}$ and 0.44 to $0.0 \mathrm{Ma}$, respectively). Glacial advances between 1.5 and $0.44 \mathrm{Ma}$ are thought to have covered extensive areas of the entire Barents Sea shelf. Large-scale glacial erosion resulted in seabed sculpturing and development of the URU [18]. According to calculations of Laberg et al. [34], 330-420 m of sediments were eroded during this time span. It is unknown how much glacial deposition occurred during this period in the study area, since no preserved on-shelf sediments exist, but a lack of deposits suggests net erosion in the study area and further to the east during that period. Since $440 \mathrm{ka}$, glaciations have been mostly confined to the ice stream areas including the Bear Island Trough. In contrast, between $440 \mathrm{ka}$ and the present, the outer shelf area experienced net accumulation and shelf aggradation although erosional processes in the area lead to $440-530 \mathrm{~m}$ of erosion [1, 18, 34, 62]. The amount of actual deposition in the study area, being a transition between mostly erosive inner shelf and depositional outer shelf, is unknown and 
that issue is addressed here in this paper. The change in sedimentary conditions in the Middle Pleistocene might have been related to changes in glacial regime, sediment supply and differential subsidence [18]. The main erosion mechanism during the two periods (pre- and post-440 ka) was subglacial erosion [34]. Erosion during interglacials in the outer shelf areas is rather doubtful since evidence for deposition during some interglacials has been described [62].

\section{Methodology}

The Pleistocene contribution to the net erosion was assessed in the western Barents Sea at the locations of eight exploration wells (see Fig. 1; Table 1).

\section{Glacial contribution to the net erosion: Monte Carlo method}

The contribution is calculated as a balance between total deposition and total erosion thickness. Deposition and erosion thicknesses are calculated for each glacial and interglacial period starting at $1.60 \mathrm{Ma}$ (coinciding with the onset of marine-glaciomarine conditions in the study area, see "Introduction") and ending at the present day. The glacial/interglacial ages are based on inferred ages of glaciations using the method described below.

The present-day Pleistocene-Holocene sediment thickness $[T(\mathrm{~m})]$ is a result of sediment deposition during both warm periods and glaciations, as well as of removal of sediments related to glacial erosion (Eq. 1). It is assumed that glacially driven erosion is the only erosion mechanism in the area and that there was no erosion during warm periods (see above). During glaciations, the net deposition thickness is calculated independently for the 1600-440 ka and 440-0 ka intervals because of different sedimentary conditions during the different periods (see above).

The equation for calculating thickness $T$ is:

$$
\begin{aligned}
T= & \mathrm{DR}_{\text {warm }} \sum_{i=1}^{n} D_{\text {warm }, i} \\
& +\mathrm{NDR}_{\text {glac, }, 1600-440 \mathrm{ka}} \sum_{i=1}^{m 1600-440 \mathrm{ka}} D_{\text {glac }, i} \\
& +\mathrm{NDR}_{\text {glac }, 440-0 \mathrm{ka}} \sum_{i=1}^{m 440-0 \text { ka }} D_{\text {glac }, i},
\end{aligned}
$$

where $D_{\text {warmx }, i}=$ duration of $i$ th warm period (ka), $D_{\text {glac }, i}=$ duration of $i$ th glacial event $(\mathrm{ka}), \mathrm{DR}_{\mathrm{warm}}=\mathrm{av}-$ erage deposition rate $(\mathrm{mm} / \mathrm{a})$ during warm periods, $\mathrm{NDR}_{\text {glac }}=$ average net deposition rate $(\mathrm{mm} / \mathrm{a})$ during glacial events (the second subscript indicates the time interval), $n=$ number of warm periods, and $m=$ number of glacial periods (the numbers indicate the time interval).

As part of the Monte Carlo approach, glacial net deposition prior to $440 \mathrm{ka}$ and warm-period deposition rates (NDR glac,1600-440 ka, $\mathrm{DR}_{\text {warm }}$ ) for each simulation run are selected randomly from predefined uniform distributions with a range based on literature values. No estimates are available for net deposition rate during cold periods after $440 \mathrm{ka}\left(\mathrm{NDR}_{\mathrm{glac}, 440-0 \mathrm{ka}}\right)$; therefore, Eq. 1 cannot be solved uniquely. However, it is still possible to obtain some constraints on the sedimentary conditions by using a statistical method. For this a Monte Carlo simulation approach appears to be a suitable solution for assessing deposition rates during glaciations. Another advantage of the Monte Carlo method is that it provides a reasonable solution for testing wide distributions of initial/expected input parameters. Resulting parameter distributions include only those that produce output that falls within observed values [46].

The random input values are then used to calculate the Pleistocene-Holocene sediment thickness using Eq. 1. If calculated present-day thickness of the sediments matches measured values (from the boreholes), values of erosion and deposition rates for that run are considered as reflecting possible past sedimentary conditions. The difference between deposition and erosion thickness gives the value of glacial contribution to the net erosion. The approach was
Table 1 Locations where sedimentary conditions were assessed (corresponding to well locations)

\begin{tabular}{llll}
\hline Well name & Latitude N & Longitude E & Nordland group thickness [m] \\
\hline $7218 / 11-1$ & 72.09138889 & 18.43305556 & 294 \\
$7219 / 8-1 \mathrm{~S}$ & 72.37470689 & 19.39263144 & 161 \\
$7317 / 10-\mathrm{U}-1$ & 73.14972222 & 17.27027778 & 143 \\
$7218 / 8-1$ & 72.33361111 & 18.47722222 & 138 \\
$7219 / 9-1$ & 72.40039954 & 19.95139495 & 104 \\
$7220 / 6-1$ & 72.55368878 & 20.98899194 & 83 \\
$7220 / 8-1$ & 72.4915578 & 20.33212252 & 58 \\
$7220 / 5-1$ & 72.51704508 & 20.33959326 & 50 \\
\hline
\end{tabular}

Thickness of the glacigenic deposits (Nordland Group). Information from NPD fact-pages (http://factpages. npd.no/) and Sættem et al. [62] 
designed for estimation of the glacial contribution to the net erosion in the study area shown in Fig. 1. Because the glacial history of the outer Bear Island Trough differs from the other parts of the Barents Sea shelf (see "Study area and geological setting") the same criteria and simulation constraints (presented below) cannot be used in the wider Barents Sea area.

In Monte Carlo simulations, a substantial number of runs is required to obtain meaningful results. In the present study, it was found that 10 million runs was a sufficient number for each well location, as the calculated glacial deposition rates changed by a fraction less than 0.01 if the number of runs was increased. From this total number, 19,000-24,000 were 'matching runs' where the simulated thickness is equal to the measured core thickness (the exact number depends on the location).

The calculations of the present-day sediment thickness do not include calculations of sediment compaction due to ice-sheet and sediment loading. The effect of the ice loading on compaction level is a complex topic governed by past subglacial meltwater flux [6] which is not known for the study area during the modelling time-span. The effect of the ice loading is therefore neglected in the study. The effect of the compaction due to sediment loading is also not considered in calculations because it only has a small influence. The compaction will not exceed $2 \%$ when calculated using porosity-depth relations [56] using the sand-silt lithology of the Nordland Group [10], and assuming the maximum thickness of Pleistocene-Holocene deposits was reached at the present day.

\section{Ages and durations of glaciations}

To be able to use Eq. (1), ages and durations of glacial and interglacial periods $\left(D_{\text {warm }}, D_{\text {glac }}\right)$ were calculated as the first step. The durations are also used for calculating the net deposition rates (negative values) from the erosion thickness estimates given in the literature. The net deposition rates are then also used as an input to the budget calculations.

The method to determine the ages used here is based on a regional ice volume model and local LGM retreat ages based on calibrated radiocarbon ages [66]. It is assumed that the repeated glaciations followed the same pattern, so that for each area the same total volume of ice was needed for the area to be reached during each glaciation. Thus glaciation times can be determined if the history of the glacial volume is known. Such an ice volume history was presented by de Boer et al. [11] and is shown in Fig. 2. The model is primarily based on the LR04 benthic $\delta^{18} \mathrm{O}$ record [42]. The ice sheet extent and volume are calibrated to the LGM data and to the sea level records [11]. The method uses the ice sheet volume values during the LGM retreat as threshold values for describing glaciations in a specific area. Times when the ice sheet volume exceeded the threshold volume are considered to represent glacial events, while during interglacials the ice sheet volume was smaller than the threshold volume. The times when the volumes are equal to the threshold volume indicate the onset and termination ages (and thus yield durations) of the individual warm and cold periods (see Fig. 2). For many areas, the age of the LGM retreat is reasonably well known from literature. By using these ages, it might be determined what ice volume is needed to reach the area based on the Eurasian ice sheet model of de Boer et al. [11] (Fig. 2).

The accurate determination of sedimentary conditions depends on good time constraints, hence the method needs to be checked for its reliability. This check is performed here in two ways. The first is to compare glacial events reported in the literature for all marine isotope stages (MIS) since the first glaciation during the Pleistocene with this study's inferred glacial events. The second compares literature LGM glaciation onsets with the calculated onsets, i.e. older ages than the retreat ages used in the method and representing a different mechanism. The first check is not possible in the Barents Sea, because of a lack of data. Therefore, the test is performed in northeastern Poland. The Poland test-case (Szeszupa Depression, [15]) was selected because the glacial history of the northeastern Poland is relatively well understood thanks to well preserved on-land deposits and correlation with evidence from Ukraine and Belarus ([8, 41, 44], see Fig. 3). In contrast to most areas in Europe, in Poland there is a relatively good understanding both of glaciations prior to MIS 12 and younger ones [8, 41]. The second check was performed in the study area-the western Barents Sea-as well as in the southeastern Barents Sea (borehole no. 142, northern Kanin Bank margin, [52], see Fig. 1). Performing the additional check in the eastern Barents Sea also means a comparison can be made between the glacial histories of the southeastern and western Barents Sea since $\sim 1.0$ Ma.

\section{Input values and simulation constraints for the Monte Carlo simulations}

\section{Information from wells}

Values of the glacial cover thickness $T$ were obtained from exploration wells (Fig. 1) as reported by the Norwegian Petroleum Directorate (http://factpages.npd.no/, Nordland Group thickness) and from literature (Sættem et al. [62], Table 1 with all information). The thickness values have a $1 \mathrm{~m}$ precision. For this reason a deviation of $\pm 0.5 \mathrm{~m}$ from reported values is accepted for the simulation runs to be considered as 'matching' the measured cover thickness. 
Fig. 2 Eurasian ice sheet volume history curve [11] shown by the blue line, and the LGM deglaciation threshold values (black lines) used for determination of glacial events. An LGM deglaciation age $=16 \mathrm{ka}$ was used for determination of glacial events in the western Barents Sea (the study area, [66]), $14.9 \mathrm{ka}$ in the eastern Barents Sea [52], and 14.3 in northeastern Poland [15]

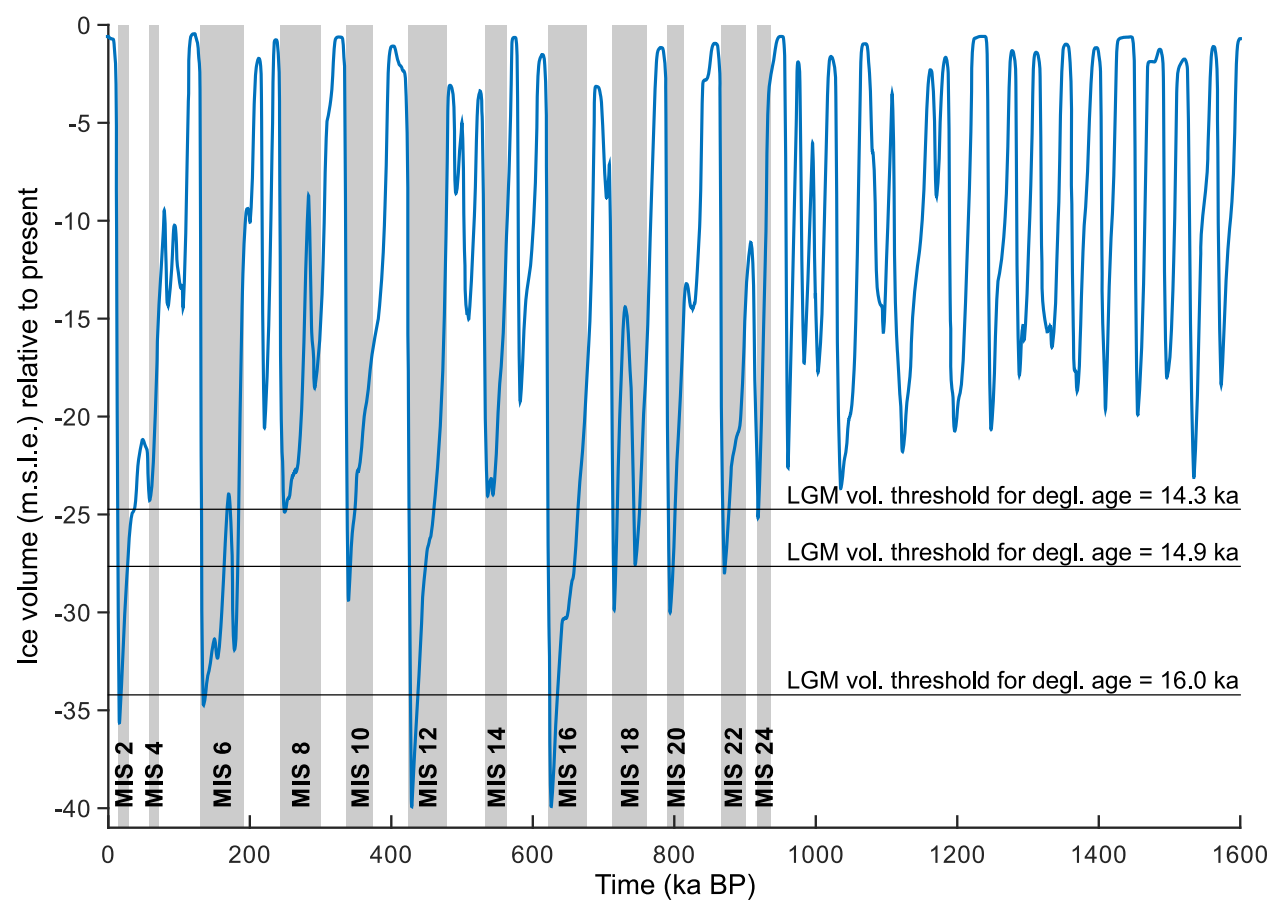

\section{Net deposition rates during glacial periods (NDR glac)}

The net deposition rates during pre-440 ka glaciations (the unknown values $\mathrm{NDR}_{\text {glac, } 1600-440 \mathrm{ka}}$ ) were constrained by using a combination of erosion estimates [34] and total duration of the glacial events prior to $440 \mathrm{ka}$.

The minimum value $(-38.36 \mathrm{~mm} / \mathrm{a})$ of the initial distribution range for pre-440 ka glaciations was calculated by dividing the maximum value of glacial erosion for the time period $1600-440 \mathrm{ka}(420 \mathrm{~m})$ by the total duration of pre-440 ka glacial events. The maximum value was set as zero reflecting a hypothetical condition when the same amount of erosion is counteracted by the same amount of deposition (see "Study area and geological setting"). The glacial erosion before $440 \mathrm{ka}$ is believed to include erosion of pre-glacial rocks [34]. For this reason those Monte Carlo simulation runs that do not lead to erosion of pre-glacial deposits are filtered out even if the modelled present-day sedimentary cover thickness matches the observed data. Thus, the filtering is applied to input values related to the time before and after $440 \mathrm{ka}$, and the periods are treated equally. None of the input parameters resulting in 'non-matching' runs are stored nor considered in resulting distributions. The upper $(5.5 \mathrm{~mm} / \mathrm{a})$ and lower $(-15.5 \mathrm{~mm} / \mathrm{a})$ limits of post-440 ka glacial deposition rates $\left(\mathrm{NDR}_{\text {glac,440-0 ka }}\right)$ were found during the Monte Carlo simulations by rejecting non-matching runs. An initial range was set by trial and error to ensure it was larger than the final range.

\section{Deposition rates during warm periods $\left(\mathrm{DR}_{\mathrm{warm}}\right)$}

The Holocene sedimentation rates from the southwestern Barents Sea were used as average sedimentation rates during the Pleistocene warm periods. No values were available at the locations of the cores used for the sedimentation calculations (see Table 1), so values were used from nearby cores which were drilled at comparable water depths and with a comparable lower shelf sedimentation regime (see Fig. 1). Pathirana et al. [50] evaluated the reliability of ${ }^{137} \mathrm{Cs},{ }^{210} \mathrm{~Pb}$ and ${ }^{14} \mathrm{C}$ dating methods used for the assessment of Holocene sedimentation rates in the western Barents Sea. They calculated Holocene sediment thickness by using these dating results and compared calculations with a Holocene thickness map. They found that only ${ }^{14} \mathrm{C}$ dating produces matching thicknesses while the other methods show considerable misfit. Based on their results it was decided to use only sedimentation rates inferred from the cores which were dated using the ${ }^{14} \mathrm{C}$ method. The rates based on this method range from 0.04 to $0.20 \mathrm{~mm} / \mathrm{a}$ (Table 2). This range was used for the minimum and maximum values of warm-period-sedimentation rates for the entire modelling time-span.

\section{Results}

\section{Ages of glaciations}

The determination of the ages of the glaciations is shown graphically in Fig. 2, where the horizontal lines are the 
Table 2 The Holocene sedimentary data used for constraining deposition rates during the warm periods

\begin{tabular}{|c|c|c|c|c|c|c|c|}
\hline Core ID & Latitude $\mathrm{N}$ & Longitude E & $\begin{array}{l}\text { Water } \\
\text { depth }(m)\end{array}$ & $\begin{array}{l}\text { Thickness of } \\
\text { deposits (mm) }\end{array}$ & $\begin{array}{l}\text { Deposition } \\
\text { duration (a) }\end{array}$ & $\begin{array}{l}\text { Deposition } \\
\text { rate }(\mathrm{mm} / \mathrm{a})\end{array}$ & References \\
\hline JM05-085 & 71.61727 & 22.91866 & 408 & 3580 & 18,340 & 0.20 & Junttila et al. [27] \\
\hline JM09-KA03-GC & 72.73184 & 16.19166 & 427 & 1790 & 16,580 & 0.11 & Rüther et al. [55] \\
\hline JM08-0309-GC & 72.48498 & 17.00743 & 385 & 690 & 17,090 & 0.04 & Rüther et al. [55] \\
\hline JM07-09-GC & 72.32213 & 17.50715 & 378 & 1270 & 16,920 & 0.08 & Rüther et al. [55] \\
\hline JM08-0306-GC & 72.98282 & 19.50758 & 416 & 430 & 6900 & 0.06 & Rüther et al. [55] \\
\hline
\end{tabular}

Table 3 Inferred ages and durations of glaciations in the western (outer Bear Island Trough, W) and eastern (northern Kanin Bank margin, E) Barents Sea areas

\begin{tabular}{|c|c|c|c|c|c|c|}
\hline $\begin{array}{l}\text { MIS } \\
\text { number }\end{array}$ & $\begin{array}{l}\text { Modelled } \\
\text { glaciation (W) }\end{array}$ & $\begin{array}{l}\text { Modelled } \\
\text { glaciation (E) }\end{array}$ & $\begin{array}{l}\text { From-to } \\
\text { (W) (ka) }\end{array}$ & $\begin{array}{l}\text { Duration } \\
\text { (W) (ka) }\end{array}$ & $\begin{array}{l}\text { From-to } \\
\text { (E) }(\mathrm{ka})\end{array}$ & $\begin{array}{l}\text { Duration } \\
\text { (E) (ka) }\end{array}$ \\
\hline 2 & Yes & Yes & $19.3-16.0$ & 3.3 & $28.3-14.9$ & 13.4 \\
\hline 4 & - & - & & & & \\
\hline \multirow[t]{2}{*}{6} & Yes & Yes & $138.6-134.6$ & 3.9 & $164.9-133.1$ & 31.8 \\
\hline & - & Yes & & & $184.1-176.5$ & 7.6 \\
\hline 10 & - & Yes & & & $343.2-339.4$ & 3.8 \\
\hline 12 & Yes & Yes & $438.7-428.0$ & 10.7 & $449.3-426.5$ & 22.8 \\
\hline 16 & Yes & Yes & $635.6-624.7$ & 11.0 & $659.5-622.7$ & 36.9 \\
\hline 18 & - & Yes & & & $718.1-714.7$ & 3.3 \\
\hline 20 & - & Yes & & & $798.9-793.3$ & 5.6 \\
\hline 22 & - & Yes & & & $872.6-870.6$ & 2.0 \\
\hline
\end{tabular}

Total duration

$28.8 \mathrm{kyr}$

$127.2 \mathrm{kyr}$

The table also shows the presence of freshwater pulses from the Central Arctic Ocean, Yermak Plateau and Fram Strait recorded at the end of the glacial events [29]. Ages of marine isotope stages (MIS) are from Lisiecki and Raymo [42]

volume thresholds for Poland (Dzierżek and Zreda [15], deglaciation age $14.3 \mathrm{ka}$, highest line), the eastern Barents Sea (Polyak et al. [52], deglaciation age $14.9 \mathrm{ka}$ ), and the western Barents Sea (Winsborrow et al. [66], deglaciation age $16 \mathrm{ka}$, the lowest line). The start and end ages and the glaciation durations, found by determining the intersection of the threshold ice ages and the ice volume curve, are given in Fig. 2 and Table 3. For the Poland test-case, the intersections show 12 glacial events during 11 marine isotope stages (see Fig. 3 for exact ages). For the eastern Barents Sea 9 glaciations during 8 marine isotope stages were found where 4 occurred before and 4 after $440 \mathrm{ka}$ and one glaciation started before $440 \mathrm{ka}$ and ended after $440 \mathrm{ka}$. The number of glaciations compares reasonably well albeit not completely with the results of Laberg and Vorren [36]. They postulated, based on seismic analysis of the depositional record of the Bear Island Trough Mouth Fan, that 8 glacial advances reached the western shelf break during the LateMiddle Pleistocene. Laberg and Vorren [36] mention, however, that during one marine isotope stage more than one ice-sheet advance can be expected. This was the case during MIS 5, when two major glaciations took place
[40, 61]. For the western Barents Sea 4 glaciations were found, suggesting that of the 9 events in the southeastern Barents Sea, only 4 reached the shelf break in the western part during the last 1 Ma: one pre-440 ka glacial event and 3 post-440 ka events (Table 3). In the western Barents Sea, the total duration of glacial events was found to be short $(28.8 \mathrm{ka})$ compared to the southeastern Barents Sea $(127.2 \mathrm{ka})$ : the total duration of glaciations in the southeast is approximately $100 \mathrm{ka}$ longer than in the west. The glacial events that reached both areas lasted much longer in the southeast than in the west (Table 3). The reason for this difference might be that the oceanic and climatic conditions favoured a thick and relatively stable ice sheet with its centre in the eastern Barents and Kara Seas like during the Weichselian [40, 51]. The western Barents Sea shelf on the other hand, was not near the ice centre, but at the ice margin, where relatively thin and unstable ice covered the area only during relatively short time-periods and not as often as in the east $[36,51,55,66]$.

To check the reliability of the age determination in northeastern Poland, modelled glacial events can be compared with terrestrial evidence of glaciations during the 


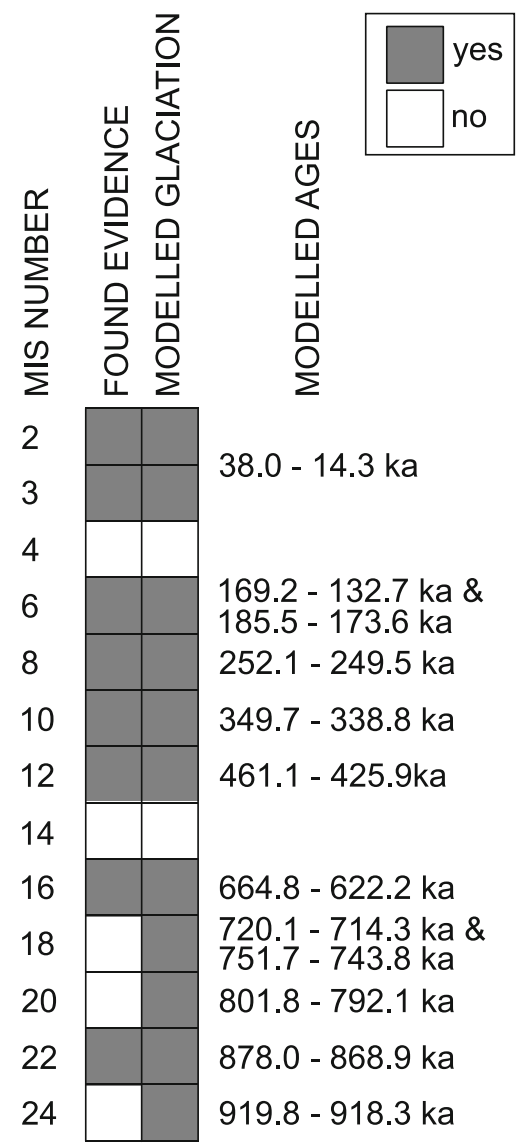

Fig. 3 Comparison between modelled glaciation events with terrestrial evidence $[41,44]$ in northeastern Poland. Ages of marine isotope stages (MIS) are from Lisiecki and Raymo [42]. The figure also shows ages of the modelled glacial events

same marine isotope stages. The descriptions from Marks [44] and Lindner et al. [41] show excellent correlation during the youngest marine isotope stages (from MIS 2 to MIS 16, Fig. 3). However, some of the older inferred glacial events are not supported by field observations (glaciations during MIS 18, MIS 20 and MIS 24). This difference is not necessarily caused by a method error but may rather be related to a lack of field evidence. The terrestrial indicators of pre-MIS 12 glaciations in northern Europe are limited [8]. This might be an effect of either evidence removal by later glaciations, or because the evidence has been misinterpreted or not discovered yet [8]. In fact, glaciations during marine isotope stages 18, 20 and 24 were identified in the North Sea Basin, Ireland, Britain, and Bay of Biscay [8], so it is possible that such glaciations also occurred in northeastern Poland. Nonetheless, by looking only at those marine isotope stages for which glaciation evidence is certain in northeastern Poland, the method works well.

In the Barents Sea, the reliability of the method can be checked by comparing LGM glaciation onsets as reported in the literature with modelled glacial onsets in the western and eastern Barents Sea. These onset ages are closest to the ages of the end of the last glaciations, so that a wrongly chosen LGM end age will result in incorrect onset ages. In this study, modelled glacial onset ages in the Barents Sea (19.3 ka in the western and $28.3 \mathrm{ka}$ in the eastern Barents Sea) fit well with estimates of the LGM onset maximum age (26-36 ka, [66]). In addition, data from the outer Bear Island Trough indicate an onset of the LGM glaciation after 21-22 ka [38, 39] supporting the modelled onset in the western Barents Sea.

A good fit of modelled glacial events with the literature events (the Poland test-case) as well as good correlation of the calculated LGM glaciation onset ages with the literature ages indicates that the method gives realistic results. Thus the method provides reasonable estimates of the glacial durations at least for the Middle-Late Pleistocene glaciations (the last $600-700 \mathrm{ka}$ ), so the ages found this way can be used with some confidence in the determination of the sedimentation conditions.

\section{Sedimentary conditions}

Although all input values in the Monte Carlo simulations are drawn from uniform distributions for the 1 million runs, the accepted input values that lead to the correct thicknesses follow different distributions, as shown in Fig. 4a-c. The output values (Fig. 4d) also follow distributions that are not uniform.

\section{Average deposition rates during warm periods}

The input variables are deposition rate during warm periods, and net deposition rates during glacial periods before and after $440 \mathrm{ka}$. The mean values for deposition rate during warm periods are similar for all wells: $0.11-0.13 \pm 0.05 \mathrm{~mm} / \mathrm{a}$ (Table 4; Fig. 4a). The distribution of the values shows, however, that the most likely values are at the lower end of the range, except for well 7220/5-1 (which has the thinnest Nordland Group deposits); in this well the most likely values are at the upper end of the input range.

\section{Glacial deposition rates before $440 \mathrm{ka}$}

The net deposition rates during glacial periods before $440 \mathrm{ka}$ are negative (Fig. 4b; Table 4), indicating net erosion for all wells. The most likely values lie between the lower end of the range and values slightly higher than the mean; (approximately between -38 and $-18 \mathrm{~mm} / \mathrm{a}$ ); very few runs resulted in net glacial deposition rates at the higher end of the range. The mean values of the glacial net deposition rates after $440 \mathrm{ka}$ in all wells are similar, with an average of $-24.2 \pm 8.5 \mathrm{~mm} / \mathrm{a}$. 

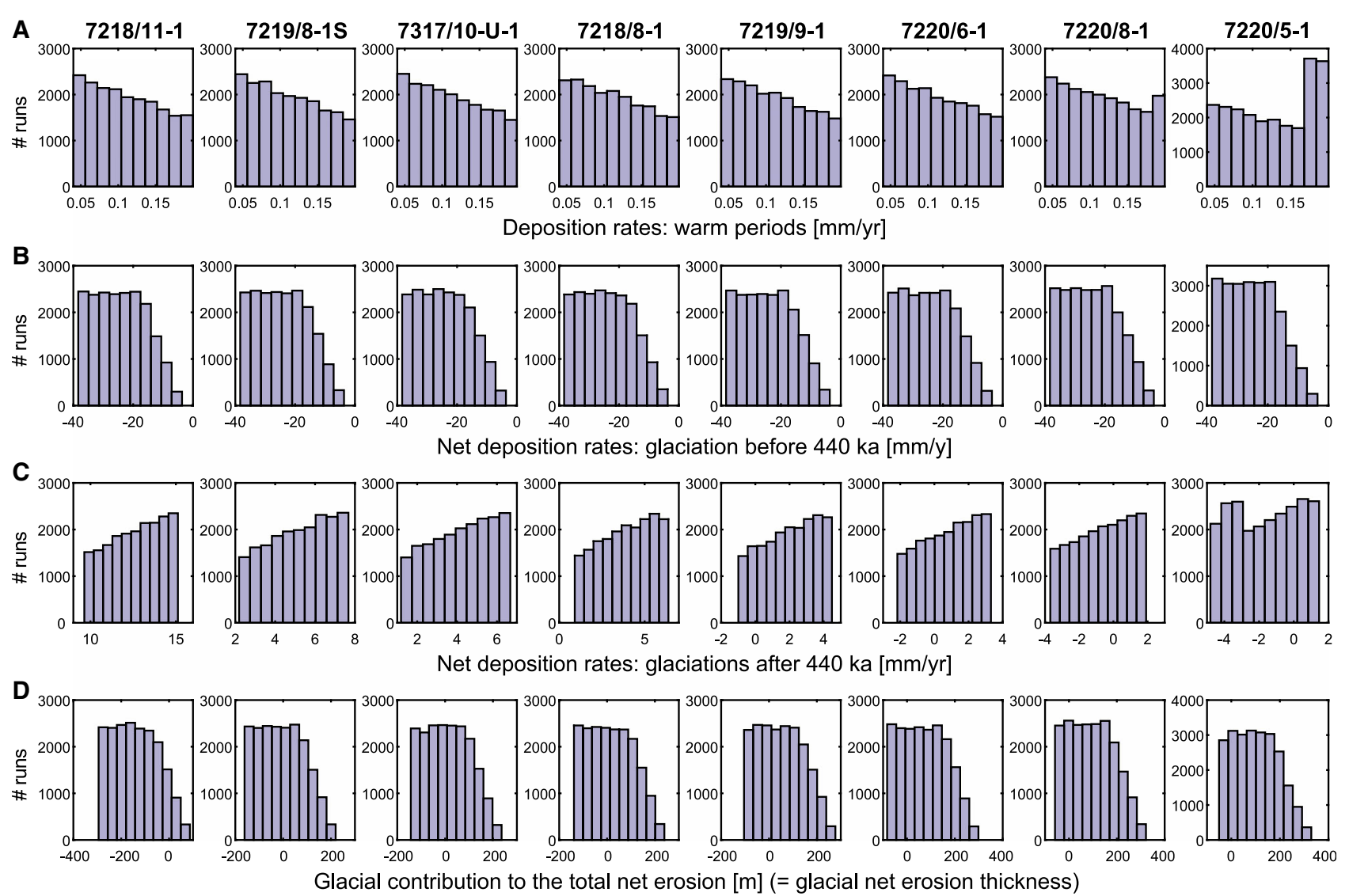

Fig. 4 Input values $(\mathbf{a}-\mathbf{c})$ and output values $(\mathbf{d})$ for all eight cores that lead to a modelled thickness that matched the measured thickness. Due to this restriction, the acceptable input values do not show a uniform distribution

\section{Glacial deposition rates after $440 \mathrm{ka}$}

The values of the final input variable, net deposition rates during glacial periods after $440 \mathrm{ka}$, show more or less the opposite trend of those before $440 \mathrm{ka}$ (Fig. 4c; Table 4): the most likely values lie at the upper end of the range, except for well 7220/5-1 (with the thinnest Nordland Group deposit). The mean, minimum and maximum values of net deposition decrease with decreasing Nordland Group deposit thickness, from 12.6 to $-1.6 \mathrm{~mm} / \mathrm{a}$, i.e. from net deposition (six thickest deposits) to net erosion (two thinnest deposits).

\section{Glacial contribution to the total net erosion}

The glacial contributions to the total net erosion, the output of the calculations, are shown in Fig. $4 \mathrm{~d}$ and Table 5 for all locations. Figure $4 \mathrm{~d}$ shows that the most likely values are at the lower half of the range, with few runs resulting in very high net erosion values. The spread in the outcome as given by the standard deviation is comparable for all locations and is $90-94 \mathrm{~m}$. The results in Table 5 and Fig. 4d show that Nordland Group thickness and glacial
Pleistocene net erosion thickness are correlated: the thinner the deposit, the higher the minimum and maximum values of the glacial net erosion thickness. The mean value increases with decreasing deposit thickness from $-139 \pm 94 \mathrm{~m}$ for the thickest deposit, to $101 \pm 90 \mathrm{~m}$ for the thinnest deposit. This correlation is very strong, with a correlation coefficient of 0.99 . Because of this, net deposition (negative net erosion values) is most likely for the wells with the thickest deposits, while net erosion (positive net erosion values) is most likely for the wells with the thinnest deposits. When glacial erosion is larger than deposition during the glacial and interglacial periods, erosion of pre-glacial deposits (bedrock erosion) will take place. From the results obtained here, the amount of this erosion can be determined simply as the present-day thickness of glacigenic deposits plus the net glacial erosion.

\section{Relationships between the sedimentological parameters}

The results in Fig. 4 are shown as histograms, in which relations between variables are not included. Due to the restrictions included in the calculations (present-day thickness, erosion before $440 \mathrm{ka}$ ), not all variables are 
Table 4 Minimum, maximum, mean and standard deviation (std) values of the modelling input values calculated by using the Monte Carlo approach for different well locations

\begin{tabular}{|c|c|c|c|c|c|c|c|c|}
\hline Well no. & $7218 / 11-1$ & $7219 / 8-1 S$ & 7317/10-U-1 & $7218 / 8-1$ & $7219 / 9-1$ & $7220 / 6-1$ & $7220 / 8-1$ & $7220 / 5-1$ \\
\hline \multicolumn{9}{|c|}{ Deposition rate during warm periods $(\mathrm{mm} / \mathrm{a})$} \\
\hline Min & 0.04 & 0.04 & 0.04 & 0.04 & 0.04 & 0.04 & 0.04 & 0.04 \\
\hline Max & 0.20 & 0.20 & 0.20 & 0.20 & 0.20 & 0.20 & 0.20 & 0.20 \\
\hline Mean & 0.11 & 0.11 & 0.11 & 0.11 & 0.11 & 0.11 & 0.12 & 0.13 \\
\hline Std & 0.05 & 0.05 & 0.05 & 0.05 & 0.05 & 0.05 & 0.05 & 0.05 \\
\hline \multicolumn{9}{|c|}{ Pre-440 ka deposition rate $(\mathrm{mm} / \mathrm{a})$} \\
\hline Min & -38.36 & -38.35 & -38.35 & -38.35 & -38.35 & -38.35 & -38.36 & -38.35 \\
\hline Max & -3.67 & -3.66 & -3.66 & -3.73 & -3.68 & -3.61 & -3.63 & -3.61 \\
\hline Mean & -24.15 & -24.16 & -24.17 & -24.14 & -24.17 & -24.20 & -24.26 & -24.75 \\
\hline Std & 8.50 & 8.52 & 8.52 & 8.52 & 8.55 & 8.52 & 8.51 & 8.28 \\
\hline \multicolumn{9}{|c|}{ Post-440 ka deposition rate $(\mathrm{mm} / \mathrm{a})$} \\
\hline Min & 9.64 & 2.19 & 1.19 & 0.91 & -0.99 & -2.17 & -3.69 & -4.80 \\
\hline Max & 15.12 & 7.67 & 6.67 & 6.39 & 4.48 & 3.31 & 1.91 & 1.46 \\
\hline Mean & 12.60 & 5.17 & 4.17 & 3.87 & 1.97 & 0.80 & -0.68 & -1.59 \\
\hline Std & 1.56 & 1.55 & 1.55 & 1.54 & 1.55 & 1.56 & 1.60 & 1.84 \\
\hline
\end{tabular}

Table 5 Values of the Pleistocene contribution to net erosion compared with measured values of the net erosion from Henriksen et al. [24]

\begin{tabular}{|c|c|c|c|c|c|c|c|c|}
\hline Well no. & 7218/11-1 & $7219 / 8-1 \mathrm{~S}$ & 7317/10-U-1 & 7218/8-1 & 7219/9-1 & $7220 / 6-1$ & $7220 / 8-1$ & $7220 / 5-1$ \\
\hline \multicolumn{9}{|l|}{ Contribution to net erosion (m) } \\
\hline Min & -294.37 & -161.39 & -143.41 & -138.36 & -104.44 & -83.27 & -58.40 & -50.42 \\
\hline Max & 86.98 & 219.36 & 236.12 & 239.53 & 277.46 & 298.39 & 321.71 & 329.15 \\
\hline Mean & -138.80 & -5.44 & 12.78 & 16.92 & 51.43 & 72.76 & 96.15 & 101.49 \\
\hline Std & 93.53 & 93.46 & 92.64 & 93.45 & 93.39 & 93.68 & 92.83 & 90.49 \\
\hline Net erosion [24] (m) & $\sim 200$ & $600-800$ & $\sim 600$ & $\sim 200$ & $1000-1200$ & $1600-1800$ & $1000-1200$ & $1200-1400$ \\
\hline $\begin{array}{l}\text { Most likely glacial erosion } \\
\text { contribution to the net erosion }\end{array}$ & Negative & Negative & $2 \%$ & $8 \%$ & $5 \%$ & $4 \%$ & $9 \%$ & $8 \%$ \\
\hline $\begin{array}{l}\text { Maximum glacial erosion } \\
\text { contribution to the net erosion }\end{array}$ & Negative & $15 \%$ & $18 \%$ & $55 \%$ & $14 \%$ & $10 \%$ & $19 \%$ & $16 \%$ \\
\hline
\end{tabular}

independent, and some variables are more dominant in the outcome. Relations between variables can be shown in cross-plots, as is done in Fig. 5. If two variables are independent of each other, then a scatter plot would show an even distribution of all values within a square defined by the limits used as input values (see literature input values above). In Fig. 5, plots of variables that are independent are not included. The figure shows results only for well 7220/5-1, but the relations are the same for all wells. Figure 5a shows deposition rates during warm periods vs. glacial net deposition rates before $440 \mathrm{ka}$. These variables are independent, except for glacial deposition rate values between ca. -17 and $-4 \mathrm{~mm} / \mathrm{a}$. No valid runs have values that plot in the upper triangle of the square; this is because of the requirement for net glacial erosion before $440 \mathrm{ka}$. During the warm period before the first glaciation, some sediment was deposited, with the amount depending on the input value of the warm period deposition rate. In order to model net erosion of pre-glacial deposits, the glacial erosion thickness during the first glaciation must overcome the thickness of sediments deposited prior to the first glaciation. This cannot occur if glacial net erosion rates are low while warm-period deposition rates are high. Because of this, few runs have high net deposition rate before $440 \mathrm{ka}$, as can be seen in Fig. 4b.

Another type of correlation is shown in Fig. 5b: deposition rates during warm periods and glacial net deposition rate after $440 \mathrm{ka}$ show a strong negative correlation. The modelled present-day thickness of glacial deposits is controlled by the balance between deposition/erosion during post-440 ka glaciations and deposition during warm periods. Low warm-period deposition rates require high deposition rates during glaciations, otherwise a present-day cover would be modelled that is too thin, and vice versa for high warm-period deposition rates and low glacial deposition rates. This relation is reflected by the frequency distribution plots of warm-period deposition rate and net deposition rate after $440 \mathrm{ka}$ (Fig. $4 \mathrm{a}, \mathrm{c}$ ): a high number of 


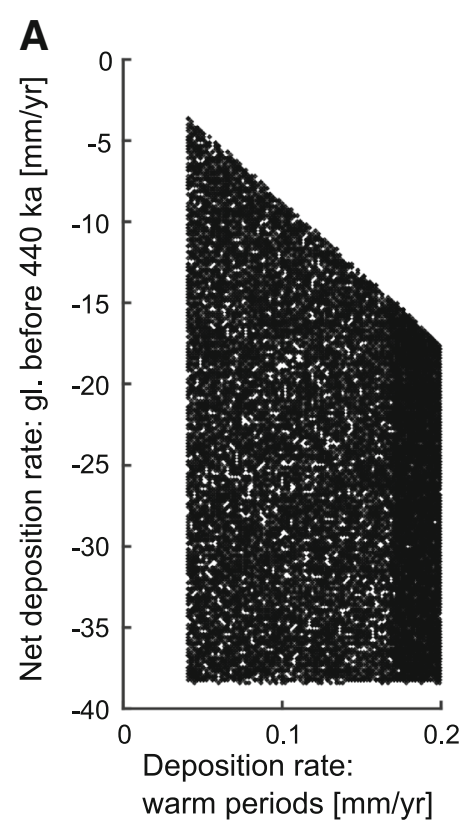

Fig. 5 Relationships between different input variables of simulation runs which result in a matching thickness of the present-day Pleistocene-Holocene cover in exploration well 7220/5-1. Each Monte Carlo simulation run is represented by one dot. a Average deposition rates during warm periods vs. net deposition rate during

low warm-period deposition rates results in a large number of high net glacial deposition rate after $440 \mathrm{ka}$ runs and vice versa. The two wells with the thinnest Nordland Group deposits, 7220/8-1 and 7220/5-1, are the only wells that show a break in the correlation slope (only the results for the latter well are shown). In well 7220/5-1 the break occurs at deposition rates during warm periods $\approx 0.17 \mathrm{~mm} /$ a and glacial net deposition rate $\approx-3 \mathrm{~mm} / \mathrm{a}$ (Fig. $5 \mathrm{~b}$ ). The left part of the plot represents conditions that do not cause complete erosion of the sediments deposited between the first and the second glaciations and do not cause any net erosion of pre-glacial deposits. The values in the right part of the plot represent conditions that lead to erosion of the sediments deposited between the first and the second glaciations and cause net erosion of pre-glacial deposits, and therefore contribute to the net erosion. The pre-glacial erosion thickness due to the second glaciation (438.7-428.0 ka, see Table 3) reaches a maximum of $15 \mathrm{~m}$ in well 7220/5-1. Given the frequency distribution of warm-period deposition rates (Fig. 4a), the values in the right side of the plot are more likely than the values in the left part.

A similar type of correlation between variables is seen in Fig. 5c. The glacial contribution to the total net erosion and glacial net deposition rate before $440 \mathrm{ka}$ are negatively correlated since almost all erosion of pre-glacial deposits occurs due to erosion during the first glaciation (little or no glacial erosion post-440 ka, see Fig. 4). The correlation is

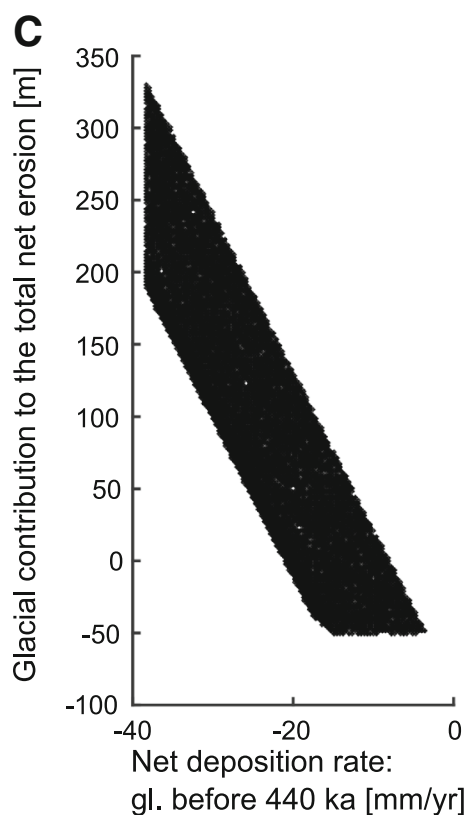

pre-440 ka glacial event, b average deposition rates during warm periods vs. average net deposition rates during post-440 ka glacial events, c net deposition rate during pre-440 ka glacial event vs glacial contribution to the net erosion. $g l$. glaciations

not as strong as the one in Fig. $5 \mathrm{~b}$ due to the different warm-period deposition rates used in the calculations. The correlation is not as strong because it is also influenced by SRW: deposition during the warm period prior to the first glaciation reduces the contribution to net erosion.

\section{Discussion}

\section{Glacial ages}

The results in Fig. 3 show that the method for determining glacial ages works, but it is very sensitive to the choice of LGM retreat age: a small shift may sometimes lead to large changes in the number of inferred glaciations. The age determination method thus relies on good possibilities to constrain the number of glaciations, and may be difficult to apply in areas where such control is not available. In the western Barents Sea, the age of the LGM retreat can be reduced by a few hundred years to keep the same number of glaciations, although the durations would of course change. Such a change would be within the uncertainty of $10^{2}-10^{3}$ years derived from radiocarbon dating for the LGM ages [51, 66], but the resulting age of the onset of the LGM (about $23 \mathrm{ka}$ for a deglaciation age of $15.5 \mathrm{ka}$ ) would not fit the reported literature value of Landvik et al. [39] and Lambeck et al. [38]. The number of glaciations in the eastern Barents Sea is more sensitive to changes, as the 
threshold volume is on the edge of indicating extra glaciations, so that reducing or increasing the LGM age would change the number of inferred glaciations. Reducing the age by a few hundred years would result in up to four extra glacial events, while increasing the age would result in 3-4 fewer glaciations. One example of this strong influence is for a possible glaciation during MIS 4. Larsen et al. [40] suggested that the entire Barents Sea might have glaciated during this time. The results presented in this paper suggest this was not the case. Larsen et al. [40] based their hypothesis mainly on ice flow direction indicators, and shape of end-moraines from inland Russia that coincided with glaciation on Svalbard [43]. The hypothesis was also supported by ice-rafted debris (IRD) and meltwater signals [57, 60] and ice volume estimations [37]. This paper is partially based on the same type of data. However, based on the ice volume model of de Boer et al. [11], a change of several hundreds to thousands of years of the LGM deglaciation age would be needed for the method used here to get a glaciation during MIS4. This would be outside the accuracy range of the evidence used to test the method, so such a glaciation is deemed unlikely. Overall, the results indicate that with this sensitivity, the results are quite reliable.

\section{Glacial history}

This study shows that during the Middle-Late Pleistocene the Barents Sea ice sheet reached the outer shelf for $3-11 \%$ of the total 100 ka-long glacial cycles (the two most recent cycles). This fits with the time ratio $(<10 \%)$ of the shelf-edge glaciations (in relation to the $100 \mathrm{ka}$ cycles) estimated for the Norwegian-Barents Sea shelves during the Weichselian [17, 47, 51]. In the eastern part, the ice sheet was generally found to be more stable, present for 13-39\% of the total glacial cycles. This ratio contains the range of 15-20\% estimated for the eastern Barents Sea during the Late Weichselian [51, 66].

Combining the timing of glaciations as found above with timings presented in the literature, a glacial history for different parts of the Barents Sea can be described as follows for the different marine isotope stages. The results in Table 3 indicate that the first major glaciations to reach the northern and southeastern part of the Barents Sea occurred during the Ionian and Calabrian stages during MIS 22 (872.6-870.6 ka), MIS 20 (798.9-793.3 ka) and MIS 18 (718.1-714.7 ka). The northern part was first reached by glaciations during MIS 20 according to the evidence given by Knies et al. [30]. The next cool periods (MIS 16, MIS 12) resulted in the first glaciations that probably covered the entire Barents Sea including the deepest parts of the Bear Island Trough (Table 3; [30]). The following cool period (MIS 10, see Table 3) resulted in an ice cover which was restricted to the eastern part of the Barents Sea. During MIS 6 (Saalian) the entire Barents Sea is thought to have been glaciated again, which is confirmed by amino acid dating of a regional till unit $[61,62]$, and the results in Table 3 fit well with this. A major glaciation covering the northern Barents and Kara seas was inferred by Knies et al. [28], Spielhagen [60] and Larsen et al. [40] during the next isotope stage, MIS 5d. Finally, during the LGM (MIS 2) the ice sheet covered the entire Barents Sea, reaching the northern and western shelf edges and the western part of the Kara Sea (Table 3; [40, 51]).

\section{Sedimentary conditions during the Pleistocene}

The Monte Carlo calculations give results for two different time periods (before and after $440 \mathrm{ka}$ ), and these two time periods show different characteristics. The glacial net deposition rate after 440 ka shows a negative correlation with the warm-period sedimentation rate, while there is little correlation of glacial net deposition rate before $440 \mathrm{ka}$ and the warm-period sedimentation rate. This indicates that the older period is dominated by glacial behaviour, while the younger period is also influenced by warm period behaviour. The pre-440 ka period shows similar negative net glacial deposition rates (i.e. net erosion) at all the well locations (Fig. 4b) implying the entire study area was dominated by homogeneous glacial erosion. In contrast, the post-440 period shows mostly positive net deposition although values are different at the different well locations. This agrees with the work of Faleide et al. [18] and Laberg et al. [34] showing that prior to $440 \mathrm{ka}$ the sedimentary conditions were mostly erosional over the western Barents Sea; while after $440 \mathrm{ka}$ conditions were aggradational.

\section{Glacial net erosion prior to $440 \mathrm{ka}$}

The numerical values of the erosion and deposition rates can be compared with the values reported in the literature. They do not always agree in an obvious manner. The most likely average erosion rates inferred in this study $(24.2 \pm 8.5 \mathrm{~mm} / \mathrm{a})$ are about one order of magnitude higher than available rates estimated for Vestfjorden, offshore northern Scandinavia [35] and Svalbard [16] for similar durations $\left(10^{3}-10^{4} \mathrm{a}\right)$. The values range from 1 to about $2 \mathrm{~mm} / \mathrm{a}$. The difference is mainly attributed to different sizes of drainage areas. The Pleistocene drainage area in the Barents Sea $\left(10^{5} \mathrm{~km}^{2}\right.$, [65]) is about two to three orders of magnitude larger than drainage basins of Svalbard's glaciers $\left(10^{2}-10^{3}\right)$ and Vestfjorden $\left(10^{3} \mathrm{~km}^{2}\right)$. Rates of glacial erosion are thought to generally increase with size of drainage basins [23, 32]. Hallet et al. [23] showed that in extreme cases an increase of the source area by one order of magnitude might result in increase in effective 
erosion rate of about one order of magnitude. Another reason for discrepancy in the erosion rates might be due to difference in lithology of the underlying bedrock. For Svalbard and northern Scandinavia the glacial erosion affected mostly crystalline rocks while dominant lithologies subcropping the Pleistocene cover in the Barents Sea include sedimentary rocks from the Triassic to the Late Cenozoic [10, 58]. Moreover, it was shown here that some glacigenic deposition prior to $440 \mathrm{ka}$ could have occured in the study area. The sediments comprise soft rocks deposited during warm periods and sediments reworked from the inner shelf by glacial transport. At present those deposits are preserved as unit GII outside the study area. They show high porosity (density is about $1.6 \mathrm{~g} / \mathrm{cm}^{3}$ ) and low compaction level [20]. The presence of easily erodible sediments in the study area might have led to higher effectiveness of the glacial erosion in the Early-Middle Pleistocene, thereby significantly increasing the erosion rates.

\section{Glacial net deposition/erosion after $440 \mathrm{ka}$}

Most of the Barents Sea shelf is covered by a thin glacigenic sedimentary unit deposited during the LGM and the Holocene [62, 64]. That unit thickens in the westernmost part of the shelf where it comprises sediments deposited during multiple episodes separated by regional unconformities possibly formed by glacial erosion [18, 62]. The main reason for the significant thickening of the succession of GIII and older glacial sequences towards the west is attributed to subsidence of the margin driven to some degree by the increased sedimentary loading [34]. Despite possible regional erosion events occurring during the Middle-Late Pleistocene, the most likely average values of net glacial deposition rates in the study area after $440 \mathrm{ka}$ are positive (i.e. net deposition, Fig. 4c), except for the two wells with the thinnest Nordland Group deposits (7220/5-1, 7220/8-1). Modelled net deposition might also be explained by pulses of increased deposition with relatively low erosion in that period. The deposition pulses could have occurred due to, for example reduction in the ice flow speed at the final stage of ice advances.

Most of the outer shelf area experienced a switch in sedimentary conditions from strong glacial net erosion before $440 \mathrm{ka}(24.2 \pm 8.5 \mathrm{~mm} / \mathrm{a})$ to glacial net deposition after $440 \mathrm{ka}(0.8-12.6 \pm 1.6 \mathrm{~mm} / \mathrm{a})$. The change in sedimentary conditions was not as significant for the two cores with the thinnest Nordland Group deposits. In those locations, glaciations both before and after $440 \mathrm{ka}$ resulted in net erosion that ranges from $0.7 \pm 1.6$ to $1.6 \pm 1.8 \mathrm{~mm} / \mathrm{a}$.

The glacial net deposition after $440 \mathrm{ka}$ and significant deposition during warm periods $(0.12 \pm 0.1 \mathrm{~mm} / \mathrm{a})$ suggest the outer shelf glacigenic cover (unit GIII) consists of both glacial and interglacial deposits at the location of all the wells except for those with the thinnest deposit. The glacial net deposition rate after $440 \mathrm{ka}$ increases with the glacial cover thickness, while deposition rate during warm periods remain more or less the same with increasing deposit thickness (see Fig. 4; Table 4). This means that thick parts of unit GIII were mostly formed by sediment transport during the post $440 \mathrm{ka}$ glaciations. In the areas where GIII is relatively thin the deposition during warm periods was more important than deposition during glaciations.

For the two locations with the thinnest deposits, the most likely net glacial deposition values are (slightly) negative (i.e. net erosion), suggesting that at those sites the present-day cover consists of interglacial deposits only. Sættem et al. [62] found for dated cores located west of the studied area (a more distal part of the fan, more or less in the middle of the Bear Island Trough Mouth Fan), that the GIII unit was formed by both glacial and interglacial sediments. Although this is not the same area (the only overlap is well 7317/10-U-01), their findings fit with the overall settings of the studied area, where the most likely values of net glacial deposition rates after $440 \mathrm{ka}$ are positive (i.e. net deposition), with corresponding low warm-period deposition rates (Figs. 4a, c, 5b).

The determined values of glacial deposition rate are lower for the studied area than those given by Sættem et al. [62], probably because this paper deals with average values for the time period covering all glaciations, while Sættem et al. [62] focuses on the LGM only. The well data of Sættem et al. [62] come from the youngest glacial deposits (unit G), which are $<30 \mathrm{ka}$ old. The thickness of this unit varies from 27 to $68 \mathrm{~m}$. Assuming the LGM lasted for $3.3 \mathrm{ka}$ in their study area, deposition rates during the LGM varies from 8 to $21 \mathrm{~mm} / \mathrm{a}$. The values found here in this paper range from slightly negative up to $13 \mathrm{~mm} / \mathrm{a}$.

\section{Pleistocene contribution to net erosion}

Table 5 and Fig. 4d show the distribution of glacial contribution to the total net erosion. All of the cores in the study area except for those with the thickest deposits (7218/11-1 and 7219/8-1S) show that there was most likely only a small contribution (2-9\%) of the glacial net erosion to the total net erosion (tectonic and glacial). The two wells with the thickest deposits experienced glacial net deposition, so the glacial processes did not contribute to the total net erosion.

The volumes of sediments deposited in the Bear Island Trough Mouth Fan as a result of the Cenozoic erosion in the Barents Sea shelf comprise approximately $70 \%$ glacial and $30 \%$ pre-glacial sediments [4]. In the study area very high glacial erosion was balanced by high glacial 
deposition of the reworked sediments. Therefore, the interpreted net erosion in the western Barents Sea or at least the outer Bear Island Trough [24] is believed to be mainly an effect of tectonic processes. This small influence of glacial erosion might have resulted in low or even no isostatic response of the lithosphere (given the erosion is compensated by isostatic uplift of about $70 \%$ as suggested by [54]). The Cenozoic uplift is usually estimated as 1 to more than $2 \mathrm{~km}[21,48]$. The uplift that is inferred in the western Barents Sea [24, 48, 54] should therefore be linked to the mechanisms occurring prior to the Pleistocene glaciations, for example those related to opening of the Norwegian-Greenland Sea [26]. It might also be speculated that low glacial contribution to the net erosion is not a local phenomenon, but rather a regional trend continuing along the Barents Sea and Norwegian Continental margins. On the Norwegian Continental margin tectonic processes are also considered to be more important than glacial erosion for generating the Cenozoic uplift [22].

The inner parts of the Barents Sea shelf were not subjected to as much sedimentation as the outer parts [18]. In the inner parts the glacigenic cover is very thin and mostly (or even entirely) represents the LGM deposits [62, 64]. It is therefore thought that a small glacial contribution to the net erosion is a phenomenon attributed only to the continental margin areas. In the inner parts glacial erosion played a much more important role in developing the net erosion. In such areas the literature ratios of glacial-totectonic erosion are higher than those presented for the western Barents Sea and vary from 33 to $66 \%$ $[9,12,14,48]$. Thus the relative contributions of glacial and tectonic processes in the Barents Sea varied considerably over the area, and such variation should be taken into account in regional reconstructions.

The results for the different wells indicate whether net erosion or net deposition is the most likely at that position. This allows a speculative boundary to be drawn between the two areas in the Barents Sea shelf that can be characterized by different Pleistocene net deposition/erosion (Fig. 1). The boundary separates the thickest core (7218/ 11-1, showing Pleistocene net deposition within its uncertainty range) and the rest of the cores (showing either both positive and negative Pleistocene net deposition or negative net deposition within their uncertainty ranges). The boundary in Fig. 1 is drawn only in the Bear Island Trough, and follows the cover thickness trends shown in Vorren et al. [64]. The line shows where the transition is between the deepest, most distal and depositional parts of the fan, and the shallower more erosive parts of the fan. Due to the small number of wells used in this study, the boundary is speculative only. The boundary indicated in Fig. 1 can also not be extended to areas outside of the trough, where different depositional processes would have acted.

\section{Conclusions}

The glacial contribution to the total net erosion in the outer Bear Island Trough (Bjørnøyrenna), western Barents Sea was evaluated. In addition, the Pleistocene deposition and erosion rates were calculated and local glacial-interglacial ages were established. The sedimentary conditions, including the glacial contribution, were determined by using a Monte Carlo-type method where different values of deposition and erosion rates are tested. Calibration is performed by comparing the modelled glacigenic cover thickness with measured thickness. The glacial-interglacial ages were found by using an approach based on the regional ice-sheet volume curve.

- The new approach used for estimation of glacial event durations was proven to be valid, showing a good correlation with reference data. Major differences in glaciation ages between the western (outer Bear Island Trough) and eastern Barents Sea were shown to result in glacial events during four marine isotope stages in the western Barents Sea one of which occurred before $440 \mathrm{ka}$ (635.6-624.7 ka, MIS 16) and three after $440 \mathrm{ka}$ (438.7-428.0, 138.6-134.6, 19.3-16.0 ka, MIS 12, MIS 6 and MIS 2, respectively). In the eastern part of the Barents Sea the glaciations were inferred during eight marine isotope stages. In addition, it was found that the total duration of glacial events was much longer in the eastern part (127 ka) than in the western part (29 ka).

- The calculated net erosion rate for a pre-440 ka glacial event is rather high $(24.2 \pm 8.5 \mathrm{~mm} / \mathrm{a})$ and homogeneous in the study area. The sedimentary conditions in the outer shelf area changed significantly from erosional (pre-440 ka) to mostly aggradational conditions after $440 \mathrm{ka}$.

- During the shelf aggradation (after $440 \mathrm{ka}$ ), glacial net deposition rates were found to vary over the study area. In the most eastern part of the area, at the very proximal end of the Bear Island Trough sedimentary wedge, the possible net deposition rates range from slightly negative (net erosion) to slightly positive values (net deposition). Further west, in the more distal part of the wedge the possible deposition rates are higher (reaching $12.6 \pm 1.6 \mathrm{~mm} / \mathrm{a}$ ) and are comparable to those previously described for the LGM [62].

- Average deposition rates during warm periods were rather homogenous in the Bear Island Trough. The most likely values were about $0.12 \pm 0.05 \mathrm{~mm} / \mathrm{a}$.

- All of the wells except for those with the thickest deposits show that there was only a small contribution of the glacial net erosion to the total net erosion. In the outer Bear Island Trough, the most likely glacial 
contribution in this area reached $100 \pm 90 \mathrm{~m}$, which is about $9 \%$ of the total net erosion. Therefore, the net erosion in the outer Bear Island Trough is believed to be mainly an effect of pre-Pleistocene tectonic processes. The two wells with the thickest deposits most likely experienced glacial net deposition, therefore not contributing to the total net erosion. The speculative boundary between the areas where the Pleistocene glaciations contributed, or did not contribute to the net erosion was established in the Bear Island Trough. The boundary is based on the basis of the glacigenic cover thickness trend and separates the core with the thickest Nordland group deposit (7218/11-1) and the rest of the cores. The Pleistocene contribution to the net erosion was found to be controlled by pre-440 ka glacial deposition rates and deposition rates during warm periods.

Acknowledgments This study is a part of the project "Impact of Cenozoic structural development and glacial erosion on gas expansion, hydraulic fracturing and leakage in the Western Barents Sea" sponsored by ENI Norge (project number 7020344). KJZ is thankful to ENI Norge for financial support of his Ph.D. and Sintef Petroleum AS for providing infrastructure and overall support. Further appreciation for Benjamin Emmel for helpful remarks and Stephen Lippard for correcting the English. We greatly appreciate the constructive comments of Jan Sverre Laberg, Willy Fjeldskaar and one anonymous reviewer which helped us in improving the manuscript.

\section{References}

1. Andreassen K, Laberg JS, Vorren TO (2008) Seafloor geomorphology of the SW Barents Sea and its glaci-dynamic implications. Geomorphology 97:157-177. doi:10.1016/j.geomorph. 2007.02.050

2. Andreassen K, Winsborrow M (2009) Signature of ice streaming in Bjørnøyrenna, Polar North Atlantic, through the Pleistocene and implications for ice-stream dynamics. Ann Glaciol 50:17-26

3. Anell I, Thybo H, Artemieva IM (2009) Cenozoic uplift and subsidence in the North Atlantic region: geological evidence revisited. Tectonophysics 474:78-105. doi:10.1016/j.tecto.2009. 04.006

4. Baig I, Faleide JI, Jahren J, Mondol NH (2016) Cenozoic exhumation on the southwestern Barents Shelf: estimates and uncertainties constrained from compaction and thermal maturity analyses. Mar Pet Geol 73:105-130

5. Bjarnadóttir LR, Rüther DC, Winsborrow MCM, Andreassen K (2013) Grounding-line dynamics during the last deglaciation of Kveithola, W Barents Sea, as revealed by seabed geomorphology and shallow seismic stratigraphy. Boreas 42:84-107. doi:10. 1111/j.1502-3885.2012.00273.x

6. Boulton GS, Dobbie KE (1993) Consolidation of sediments by glaciers: relations between sediment geotechnics, soft-bed glacier dynamics and subglacial ground-water flow. J Glaciol 39:26-44

7. Butt FA, Drange H, Elverhoi A, Ottera OH, Solheim A (2002) Modelling Late Cenozoic isostatic elevation changes in the Barents Sea and their implications for oceanic and climatic regimes: preliminary results. Quat Sci Rev 21:1643-1660. doi:10. 1016/S0277-3791(02)00018-5
8. Böse M, Lüthgens C, Lee JR, Rose J (2012) Quaternary glaciations of northern Europe. Quat Sci Rev 44:1-25. doi:10.1016/j. quascirev.2012.04.017

9. Cavanagh AJ, Di Primio R, Scheck-Wenderoth M, Horsfield B (2006) Severity and timing of Cenozoic exhumation in the southwestern Barents Sea. J Geol Soc 163:761-774. doi:10.1144/ 0016-76492005-146

10. Dalland A, Worsley D, Ofstad K (1988) A lithostratigraphic scheme for the Mesozoic and Cenozoic succession offshore mid and northern Norway. Bulletin of the Norwegian Petroleum Directorate, Bulletin no. 4, pp 1-65

11. de Boer B, Lourens LJ, van de Wal RS (2014) Persistent 400,000year variability of Antarctic ice volume and the carbon cycle is revealed throughout the Plio-Pleistocene. Nat Commun 5:2999. doi:10.1038/ncomms3999

12. Dimakis P, Braathen BI, Faleide JI, Elverhøi A, Gudlaugsson ST (1998) Cenozoic erosion and the preglacial uplift of the SvalbardBarents Sea region. Tectonophysics 300:311-327. doi:10.1016/ S0040-1951(98)00245-5

13. Doré A, Corcoran DV, Scotchman IC (2002) Prediction of the hydrocarbon system in exhumed basins, and application to the NW European margin. In: Dore AG, Cartwright JA, Stoker MS, Turner JP, White N (eds) Exhumation of the North Atlantic margin: timing, mechanisms and implications for petroleum exploration, vol 196. The Geological Society of London, London, pp 401-429

14. Duran ER, di Primio R, Anka Z, Stoddart D, Horsfield B (2013) 3D-basin modelling of the Hammerfest Basin (southwestern Barents Sea): a quantitative assessment of petroleum generation, migration and leakage. Mar Pet Geol 45:281-303. doi:10.1016/j. marpetgeo.2013.04.023

15. Dzierżek J, Zreda M (2007) Timing and style of deglaciation of north eastern Poland from cosmogenic $36 \mathrm{Cl}$ dating of glacial and glaciofluvial deposits. Geol Quat 51:203-216

16. Elverhøi A, Hooke RL, Solheim A (1998) Late Cenozoic erosion and sediment yield from the Svalbard-Barents Sea region: implications for understanding erosion of glacierized basins. Quat Sci Rev 17:209-241

17. Elverhøy A, Svendsen JI, Solheim A, Andersen ES, Milliman J, Mangerud J, Hooke RL (1995) Late quaternary sediment yield from the high arctic Svalbard area. J Geol 103:1-17

18. Faleide JI, Solheim A, Fiedler A, Hjelstuen BO, Andersen E, Vanneste K (1996) Late Cenozoic evolution of the western Barents Sea-Svalbard continental margin. Glob Planet Chang 12:53-74

19. Faleide JI et al (2008) Structure and evolution of the continental margin off Norway and Barents Sea. Episodes 31:82-91

20. Fiedler A, Faleide JI (1996) Cenozoic sedimentation along the southwestern Barents Sea margin in relation to uplift and erosion of the shelf. Glob Planet Chang 12:75-93. doi:10.1016/09218181(95)00013-5

21. Green PF, Duddy IR (2010) Synchronous exhumation events around the Arctic including examples from Barents Sea and Alaska Slope. Pet Geol Conf Ser 7:633-644. doi:10.1144/ 0070633\#Petroleum

22. Hall AM, Ebert K, Kleman J, Nesje A, Ottesen D (2013) Selective glacial erosion on the Norwegian passive margin. Geology 41:1203-1206. doi:10.1130/G34806.1

23. Hallet B, Hunter L, Bogen J (1996) Rates of erosion and sediment evacuation by glaciers: a review of field data and their implications. Glob Planet Chang 12:213-235

24. Henriksen E et al (2011) Chapter 17 Uplift and erosion of the greater Barents Sea: impact on prospectivity and petroleum systems. Geol Soc Lond Mem 35:271-281. doi:10.1144/m35.17

25. Ingólfsson Ó, Landvik JY (2013) The Svalbard-Barents Sea icesheet-historical, current and future perspectives. Quat Sci Rev 64:33-60. doi:10.1016/j.quascirev.2012.11.034 
26. Japsen P, Green PF, Bonow JM, Nielsen TFD, Chalmers JA (2014) From volcanic plains to glaciated peaks: burial, uplift and exhumation history of southern East Greenland after opening of the NE Atlantic. Glob Planet Chang 116:91-114. doi:10.1016/j. gloplacha.2014.01.012

27. Junttila J, Aagaard-Sørensen S, Husum K, Hald M (2010) Late Glacial-Holocene clay minerals elucidating glacial history in the SW Barents Sea. Mar Geol 276:71-85. doi:10.1016/j.margeo. 2010.07.009

28. Knies J, Kleiber HP, Matthiessen J, Muller C, Nowaczyk N (2001) Marine ice-rafted debris records constrain maximum extent of Saalian and Weichselian ice-sheets along the northern Eurasian margin. Glob Planet Chang 31:45-64

29. Knies J et al (2007) Effects of Arctic freshwater forcing on thermohaline circulation during the Pleistocene. Geology 35:1075-1078. doi:10.1130/G23966a.1

30. Knies J et al (2009) The Plio-Pleistocene glaciation of the Barents Sea-Svalbard region: a new model based on revised chronostratigraphy. Quat Sci Rev 28:812-829. doi:10.1016/j.quascirev. 2008.12.002

31. Knies J et al (2014) Effect of early Pliocene uplift on late Pliocene cooling in the Arctic-Atlantic gateway. Earth Planet Sci Lett 387:132-144. doi:10.1016/j.epsl.2013.11.007

32. Koppes MN, Montgomery DR (2009) The relative efficacy of fluvial and glacial erosion over modern to orogenic timescales. Nat Geosci 2:644-647

33. Laberg JS, Andreassen K, Knies J, Vorren TO, Winsborrow M (2010) Late Pliocene-Pleistocene development of the Barents sea ice sheet. Geology 38:107-110. doi:10.1130/g30193.1

34. Laberg JS, Andreassen K, Vorren TO (2012) Late Cenozoic erosion of the high-latitude southwestern Barents Sea shelf revisited. Geol Soc Am Bull 124:77-88. doi:10.1130/B30340.1

35. Laberg JS, Eilertsen RS, Vorren TO (2009) The paleo-ice stream in Vestfjorden, North Norway, over the last 35 k.y.: glacial erosion and sediment yield. Bull Geol Soc Am 121:434-447

36. Laberg JS, Vorren TO (1996) The Middle and late Pleistocene evolution of the Bear Island trough mouth fan. Glob Planet Chang 12:309-330. doi:10.1016/0921-8181(95)00026-7

37. Lambeck K, Purcell A, Funder S, Kjær K, Larsen E, Möller P (2006) Constraints on the Late Saalian to early Middle Weichselian ice sheet of Eurasia from field data and rebound modelling. Boreas 35:539-575. doi:10.1080/03009480600781875

38. Lambeck K, Purcell A, Zhao J, Svensson NO (2010) The Scandinavian ice sheet: from MIS 4 to the end of the last glacial maximum. Boreas 39:410-435. doi:10.1111/j.1502-3885.2010. 00140.x

39. Landvik JY et al (1998) The last glacial maximum of Svalbard and the Barents sea area: ice sheet extent and configuration. Quat Sci Rev 17:43-75. doi:10.1016/S0277-3791(97)00066-8

40. Larsen E et al (2006) Late Pleistocene glacial and lake history of northwestern Russia. Boreas 35:394-424. doi:10.1080/ 03009480600781958

41. Lindner L, Marks L, Nita M (2013) Climatostratigraphy of interglacials in Poland: middle and upper Pleistocene lower boundaries from a Polish perspective. Quat Int 292:113-123. doi:10.1016/j.quaint.2012.11.018

42. Lisiecki LE, Raymo ME (2005) A Pliocene-Pleistocene stack of 57 globally distributed benthic $\delta 180$ records. Paleoceanography. doi:10.1029/2004pa001071

43. Mangerud G et al (1998) Fluctuations of the Svalbard-Barents Sea ice sheet during the last 150000 years. Quat Sci Rev 17:11-42

44. Marks L (2012) Timing of the Late Vistulian (Weichselian) glacial phases in Poland. Quat Sci Rev 44:81-88. doi:10.1016/j. quascirev.2010.08.008
45. Mattingsdal R, Knies J, Andreassen K, Fabian K, Husum K, Grøsfjeld K, De Schepper S (2014) A new 6 Myr stratigraphic framework for the Atlantic-Arctic gateway. Quat Sci Rev 92:170-178. doi:10.1016/j.quascirev.2013.08.022

46. Metropolis N, Ulam S (1949) The Monte Carlo method. J Am Stat Assoc 44:335-341

47. Nygård A, Sejrup HP, Haflidason H, Lekens WAH, Clark CD, Bigg GR (2007) Extreme sediment and ice discharge from marine-based ice streams: new evidence from the North Sea. Geology 35:395-398

48. Nyland B, Jensen LN, Skagen J, Skarpnes O, Vorren T (1992) Tertiary uplift and erosion in the Barents Sea: magnitude, timing and consequences structural and tectonic modelling and its application to petroleum geology. NPF Spec Publ 1:153-162

49. Ohm SE, Karlsen DA, Austin TJF (2008) Geochemically driven exploration models in uplifted areas: examples from the Norwegian Barents Sea. AAPG Bull 92:1191-1223. doi:10.1306/ 06180808028

50. Pathirana I, Knies J, Felix M, Mann U (2014) Towards an improved organic carbon budget for the western Barents Sea shelf. Clim Past 10:569-587. doi:10.5194/cp-10-569-2014

51. Patton $\mathrm{H}$ et al (2015) Geophysical constraints on the dynamics and retreat of the Barents Sea ice sheet as a paleobenchmark for models of marine ice sheet deglaciation. Rev Geophys. doi:10. 1002/2015RG000495

52. Polyak L, Lehman SJ, Gataullin V, Jull AJT (1995) Two-step deglaciation of the southeastern Barents Sea. Geology 23:567-571. doi:10.1130/0091-7613(1995)023<0567:TSDOTS $>2.3 . C O ; 2$

53. Rasmussen E, Fjeldskaar W (1996) Quantification of the Pliocene-Pleistocene erosion of the Barents Sea from present-day bathymetry. Glob Planet Chang 12:119-133. doi:10.1016/09218181(95)00015-1

54. Riis F, Fjeldskaar W (1992) On the magnitude of the late tertiary and quaternary erosion and its significance for the uplift of Scandinavia and the Barents Sea. NPF Spec Publ 1:163-185

55. Rüther DC, Mattingsdal R, Andreassen K, Forwick M, Husum K (2011) Seismic architecture and sedimentology of a major grounding zone system deposited by the Bjørnøyrenna ice stream during late Weichselian deglaciation. Quat Sci Rev 30:2776-2792. doi:10.1016/j.quascirev.2011.06.011

56. Sclater GJ, Christie PAF (1980) Continental stretching: an explanation of the post-mid-cretaceous subsidence of the central North Sea Basin. J Geophys Res 85:3711-3739. doi:10.1029/ JB085iB07p03711

57. Siegert M, Dowdeswell JA, Hald M, Svendsen J (2001) Modelling the Eurasian ice sheet through a full Weichselian glacial cycle. Glob Planet Chang 31:367-385

58. Sigmond EM (2002) Geological map, land and sea areas of Northern Europe. Geological Survey of Norway

59. Solheim A, Kristoffersen Y (1984) Distribution of sediments above bedrock and glacial history in the western Barents Sea. Norsk Polarinstitutt Skifter 179B

60. Spielhagen R (2004) Arctic Ocean deep-sea record of northern Eurasian ice sheet history. Quat Sci Rev 23:1455-1483. doi:10. 1016/j.quascirev.2003.12.015

61. Svendsen JI et al (2004) Late quaternary ice sheet history of northern Eurasia. Quat Sci Rev 23:1229-1271. doi:10.1016/j. quascirev.2003.12.008

62. Sættem J, Poole DAR, Ellingsen L, Sejrup HP (1992) Glacial geology of outer Bjørnøyrenna, southwestern Barents Sea. Mar Geol 103:15-51

63. Vorren TO, Laberg JS (1997) Trough mouth fans-palaeoclimate and ice-sheet monitors. Quat Sci Rev 16:865-881

64. Vorren TO, Lebesbye E, Larsen KB (1990) Geometry and genesis of the glacigenic sediments in the southern Barents Sea. Geol 
Soc Lond Spec Publ 53:269-288. doi:10.1144/gsl.sp.1990.053. 01.15

65. Vorren TO, Richardsen G, Knutsen SM (1991) Cenozoic erosion and sedimentation in the western Barents Sea. Mar Pet Geol 8:317-340. doi:10.1016/0264-8172(91)90086-G

66. Winsborrow MCM, Andreassen K, Corner GD, Laberg JS (2010)

Deglaciation of a marine-based ice sheet: Late Weichselian palaeo-ice dynamics and retreat in the southern Barents Sea reconstructed from onshore and offshore glacial geomorphology. Quat Sci Rev 29:424-442. doi:10.1016/j.quascirev.2009.10.001

67. Winsborrow MCM, Stokes CR, Andreassen K (2012) Ice-stream flow switching during deglaciation of the southwestern Barents Sea. Geol Soc Am Bull 124:275-290 